ZOOLOGIA 31 (2): 195-208, April, 2014

http://dx.doi.org/10.1590/S1984-46702014000200011

\title{
Eudistoma (Ascidiacea: Polycitoridae) from tropical Brazil
}

\section{Livia de Moura Oliveira1', Gustavo Antunes Gamba' \& Rosana Moreira da Rocha ${ }^{1,2}$}

\author{
1 Programa de Pós-graduação em Zoologia, Departamento de Zoologia, Universidade Federal do Paraná. \\ Caixa Postal 19020, 81531-980 Curitiba, PR, Brazil. \\ 2 Corresponding author: E-mail: rmrocha@ufpr.br
}

\begin{abstract}
We studied material in collections from coastal intertidal and subtidal tropical waters of the Brazilian states of Paraíba, Pernambuco, Alagoas, Bahia, and Espírito Santo. We identified seven species of Eudistoma, of which two are new to science. Eudistoma alvearium sp. nov. colonies have fecal pellets around each zooid and zooids are 6-8 mm long with seven straight and parallel pyloric tubules; the larval trunk is $0.6 \mathrm{~mm}$ long with three adhesive papillae and ten ampullae. Eudistoma versicolor sp. nov. colonies are cushion-shaped, variable in color (blue, purple, brown, light green, gray or white) and zooids have six straight and parallel pyloric tubules; the larval trunk is $0.8 \mathrm{~mm}$ long with three adhesive papillae and six ampules. Three species - E. carolinense Van Name, 1945, E. recifense Millar, 1977, and E. vannamei Millar, 1977 are known from northeastern Brazil. The identification of two additional species will require confirmation. We also propose a synonymy for E. carolinense with E. repens Millar, 1977, also previously described in Brazil.
\end{abstract}

KEY WORDS. Atlantic; colonial ascidians; new species; taxonomy.

Eudistoma Caullery, 1909 is the most species-rich genus in Polycitoridae, with 124 valid species found in tropical and temperate waters, with a few records from Antarctica and the subtropics (MONNIOT 1978). Originally, Eudistoma was proposed as a subgenus of Distoma to include animals with few rows of stigmata in the pharynx (CAULlery 1909). Eudistoma was treated as a genus by RitTer \& Forsyth (1917) who did not explain why. In subsequent studies, Michaelsen (1919), VAN NAME (1921) and Токіока (1942) all considered Eudistoma as a subgenus of Polycitor. Later, VAN NAME (1945) considered Eudistoma a valid genus due to the three rows of pharyngeal slits, long esophagus, flat stomach in the posterior region of the abdomen, very conspicuous longitudinal muscles extending from the pharynx to the end of the abdomen and larvae that are incubated in the atrial cavity. While those characters are constant, color and shape are extremely variable and have caused confusion in species identification. Thus, species identification will be much more certain by using larval characters (MоNNiot 1983, Котт 1990).

Currently, 26 species of Eudistoma are known from the Atlantic Ocean, including seven in Brazil: Eudistoma carolinense Van Name, 1945, E. clavatum Rocha \& Bonnet, 2009, E. recifense Millar, 1977, E. repens Millar, 1977, E. saldanhai Millar, 1977, E. spiculiferum Millar, 1977, and E. vannamei Millar, 1977. Most are tropical, but E. carolinense and E. clavatum are found in the subtropics (Rocha \& Moreno 2000, Rocha \& BOnNet 2009).

While few records of Eudistoma spp. have been published for the Brazilian coast, we suggest that diversity is greater than expected. Here we describe material collected in eastern Brazil and comment on the implications of species richness for the distribution of Eudistoma.

\section{MATERIAL AND METHODS}

We examined material from Paraíba, Pernambuco, Alagoas, Bahia and Espírito Santo collected from 1997 to 2013 (Figs 1-4). From Paraíba, we examined both the collections deposited in the Tunicata Collection of the Laboratory of Invertebrates Paul Young of Departamento de Sistemática e Ecologia, Universidade Federal da Paraíba (LIPY/DSE/UFPB) and material recently collected (2009 and 2013) by the authors. Most of the surveys were done in the intertidal zone on many beaches along the whole coast. Samples from Pernambuco and Alagoas were very few and donated to us for identification and do not represent an extensive survey of those coasts. Samples from Bahia were collected by us using SCUBA diving at depths up to $11 \mathrm{~m}$ inside Baía de Todos os Santos and along the coast of Salvador. Main surveys occurred during one week in 1999, 2004, and 2007. In Espírito Santo, samples were also collected by us both in the intertidal and using SCUBA diving in the summer of 2011 and 2012.

Specimens were anesthetized with menthol, fixed and preserved in formalin 4\%. Dissection was with standard procedures following MoNNIOT \& MONNIOT (1972). Samples were stained with Harris hematoxylin and examined under a stereoscopic microscope. Holotypes were deposited in the Collection of the Museum of Zoology of São Paulo (MZUSP), while paratypes and additional material in the collection of ascidians from the

2014 Sociedade Brasileira de Zoologia | www.sbzoologia.org.br | www.scielo.br/zool All content of the journal, except where identified, is licensed under a Creative Commons attribution-type BY-NC. 

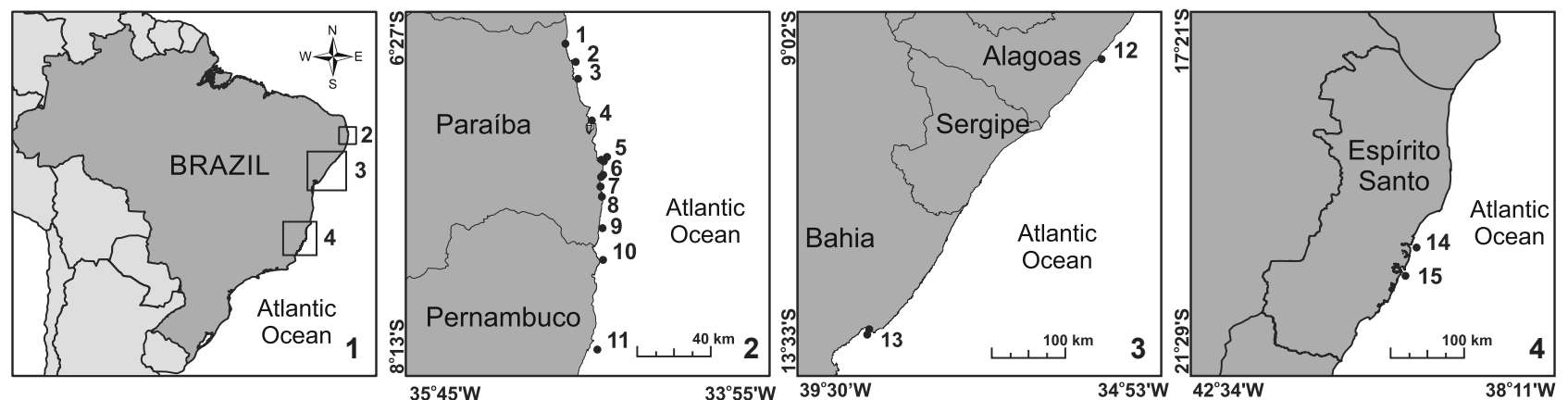

Figures 1-4. (1) Map of the Brazilian coast highlighting the study areas; (2) Paraíba and Pernambuco; (3) Bahia and Alagoas; (4) Espírito Santo. 1) Barra de Camaratuba, 2) Baia da Traição, 3) Barra de Mamanguape, 4) Quebramar Cabedelo, 5) Pomar das Esponjas, Ponta do Cabo Branco, Ponta do Seixas, Recife do Seixas, 6) Maceiozinho, Carapibus, 7) Coqueirinho, 8) Tabatinga, 9) Recife da Galé, 10) Ponta de Pedras, 11) Naufrágio do Areeiro, 12) Praia do Francês, 13) Boa Viagem, Quebramar Norte, Quebramar Sul, Farol Humaitá, Germânia e Porto da Barra, 14) Enseada das Garças, 15) Ilha dos Pacotes.

Departamento de Zoologia, Universidade Federal do Paraná (DZUP) and in the Tunicata Collection of the Laboratory of Invertebrates Paul Young of the Departamento de Sistemática e Ecologia, Universidade Federal da Paraíba (LIPY UFPB).

\section{TAXONOMY}

We found seven species of Eudistoma, of which two are new and three were already known in northeastern Brazil (Eudistoma carolinense, E. recifense, and E. vannamei). With these seven species, Brazil has approximately $39 \%$ of the Eudistoma species found in the Atlantic and $9 \%$ found worldwide. The following identification key includes all species of the genus known from Brazil. Characters used for identification are based on our morphological analysis and the literature and are described in detail in Table I.

\section{Eudistoma alvearium sp. nov. Rocha \& Oliveira} Figs $5-12$

Description. The colony measures $2.2 \times 1.6 \times 1.2 \mathrm{~cm}$ and is encrusting and cushion-shaped with irregular outline. It is brown in life and light brown in formaldehyde. The tunic is transparent, soft and gelatinous with a smooth surface. Fecal pellets are distributed throughout the colony, but in greater quantity at the top, arranged around each zooid and forming a beehive pattern that can be seen externally on the surface of the tunic.

Zooids are not arranged in systems, but are parallel to each other, occupying the space from the surface to the base of the colony, are approximately $6-8 \mathrm{~mm}$ in length when not contracted and are colorless and transparent. Both siphons open at the surface of the colony and each has six rounded lobes. The tubular oral siphon is shorter than the lateral and horizontally directed atrial siphon. Conspicuous circular muscles form a sphincter at the base of each siphon.
The body wall is transparent with conspicuous longitudinal muscles. Ten parallel longitudinal muscular fibers are on each side of the thorax. In the abdomen, muscles form two lateral-ventral bundles that extend to the posterior edge of the zooid. The transverse musculature is also conspicuous in the thorax with 16 fibers. A band of circular muscles is visible at the beginning of the abdomen. Oral tentacles were not observed due to contraction of zooids. The first row of the pharynx has 16 stigmata on each side, while the second and third have 14. The esophagus is long and straight. The stomach is spherical with smooth wall, posteriorly in the abdomen. The anterior intestine is shorter than the stomach. The pyloric gland has at least seven pyloric straight and parallel tubules, originating in the posterior region of the stomach. The intestinal loop has two constrictions, one between the anterior intestine and the middle intestine and the other between the middle and ascending intestine. The anus is at the level of the second row of stigmata.

Gonads are in the intestinal loop, just below the stomach, reminiscent of a bunch of grapes. The testis has approximately 16-20 follicles and a straight sperm duct, while the ovary is central and has 2-3 oocytes. One to three, oval shaped, 0.6 $\mathrm{mm}$ long trunk larvae are incubated in the oviduct. Larvae have three adhesive papillae and ten ampullae, three pairs along the mid anterior line, one dorsal-lateral pair and two ventral ampullae. The papillae have a wide peduncle, as long as the ampullae. The dorsal pair of ampullae and the two pairs between the adhesive papillae are elongated, the two ventral and the dorsal-lateral pair of ampullae are shorter with rounded end. Larvae have three rows of pharyngeal slits. The larval ocellus and otolith are posterior and the tail makes a one-half turn around the trunk on the left side of the adhesive papillae.

Type material. Holotype: BraziL, Bahia: Salvador (Naufrágio Boa Viagem, 1256'6"S, 38³0’42"W, 7-8 m), 1 colony, 3 slides, 03.viii.1999, Rocha, R.M. leg., (MZUSP 00035). 
Table I. Key to the identification of Eudistoma in the Brazilian coast. (1) Colony shape: $\mathrm{C}$ - cushion, $\mathrm{F}$ - fingerlike projections, $\mathrm{H}-$ heads on cylindrical peduncles, $\mathrm{S}$ - spherical. (2) Colour of living colony: $\mathrm{BI}=$ blue, B - brown, C - cream, G - grey, Gr - green, $\mathrm{O}$ - orange, $\mathrm{P}$ - purple, $\mathrm{S}$ - colour of the sand the covers the colony, $\mathrm{U}$ - uncolored, $\mathrm{Y}$ - yellow, W - white. (3) Zooid maximum reported size (mm). (4) Pigmentation of zooid: 0 - absent, P - present. (5) Organization of zooids in the colony: 0 - no systems, $S$ - with systems. (6) Calcareous spicules in the tunic: 0 - absent, $P$ - present. (7) Number of longitudinal muscle fibers in one side of the thorax. (8) Number of pharyngeal stigmata per row on each side. (9) Maximum number of testicular follicles reported. (10) Number of incubated embryos or larvae. (11) Size of larval trunk (mm). (12) Total number of ectodermal ampullae in larvae.

\begin{tabular}{|c|c|c|c|c|c|c|c|c|c|c|c|c|}
\hline 1 & 2 & 3 & 4 & 5 & 6 & 7 & 8 & 9 & 10 & 11 & 12 & Species \\
\hline $\mathrm{F}$ & $S$ & 4 & 0 & 0 & 0 & $5-6$ & $11-15$ & 13 & $1-2$ & $0.4-0.54$ & 26 & Eudistoma carolinense $e^{1,2,4}$ \\
\hline $\mathrm{H}$ & C & 7 & 0 & 0 & 0 & $12-20$ & $13-24$ & 13 & $2-4$ & 0.5 & 8 & E. clavatum ${ }^{3}$ \\
\hline $\mathrm{H}$ & B, G, Gr & 8 & 0 & $S$ & 0 & $?$ & 10 & 10 & $?$ & $0.7-0.75$ & 6 & E. saldanhai ${ }^{2}$ \\
\hline $\mathrm{H}$ & $\mathrm{Y}, \mathrm{O}$ & 20 & $\mathrm{P}$ & 0 & 0 & $12-18$ & $20-22$ & 6 & 1 & $1.2-1.4$ & 8 & E. vannamei ${ }^{2,4}$ \\
\hline C & B & 8 & 0 & 0 & 0 & 10 & $14-16$ & 20 & $1-3$ & 0.6 & 10 & E. alvearium sp. nov. \\
\hline C & s & 11 & 0 & $S$ & 0 & $28-32$ & 24 & 13 & $?$ & $?$ & $?$ & Eudistoma sp. 1 \\
\hline C & $\mathrm{U}$ & 2.2 & $P$ & 0 & 0 & $6-7$ & 15 & 10 & $1-2$ & $0.6-0.8$ & 6 & Eudistoma sp. 2 \\
\hline$C, S$ & $\mathrm{P}, \mathrm{BI}, \mathrm{B}, \mathrm{W}, \mathrm{Gr}$ & 10 & 0 & $S$ & 0 & $18-25$ & $14-16$ & 25 & 1 & $0.6-0.7$ & 6 & E. versicolor sp. nov. \\
\hline$C, S$ & G & 10 & $\mathrm{P}$ & $S$ & 0 & $12-14$ & $14-16$ & 18 & 1 & 0.6 & 6 & E. recifense $e^{2,4}$ \\
\hline C & $B, P$ & 5 & $\mathrm{P}$ & ? & $P$ & $?$ & ? & $?$ & 1 & $1-1.15$ & $?$ & E. spiculiferum ${ }^{2}$ \\
\hline
\end{tabular}

${ }^{1}$ Van Name (1945); ${ }^{2}$ Mlllar (1977); ${ }^{3}$ Rocha \& Bonnet (2009); ${ }^{4}$ Present study; ? No information.

Etymology. The specific epithet is derived from latin and refers to the beehive shape of the colony (alvearium = beehive).

Remarks. This species is unlike any other described in Brazil or elsewhere in the Atlantic Ocean. It is very distinctive in appearance with the tunic surface smooth and transparent, and zooids separated by fecal pellets and not arranged in circular systems. In the Pacific, Котт (1990) described E. constrictum, a very similar species (in the appearance of the colony). However, E. constrictum has brownish pink zooids in ethanol and the thorax contains 30 longitudinal fibers crossed by numerous transverse fibers in the middle of the thorax. Up to four embryos may be incubated in the atrial cavity. Larvae measure $1 \mathrm{~mm}$ long with the tail describing a three-quarter turn around the trunk. Larvae have three adhesive papillae and six ampullae, one dorsal, one ventral and two between each pair of papillae.

\section{Eudistoma carolinense Van Name, 1945}

Figs 13-18

Eudistoma carolinense Van Name, 1945: 123-124, fig. 58; Pérès, 1949: 170; Millar, 1977: 176-179, figs. 6, 7; Monniot, 1983: 1011-1013, fig. 4 C-F; Rocha \& Moreno, 2000: 10-11, fig. 1; Rocha \& Faria, 2005: 5; Rocha \& Kremer, 2005: 1173; Rocha et al., 2005: 463.

Eudistoma repens Millar, 1977: 184 (synonymy).

Description. Branching finger-like projections, approximately $2.5 \mathrm{~cm}$ in length and variable width, project from an encrusting base. The ends of the projections are widened and sometimes flattened. The colony is brownish because of sand accumulation in the tunic. Zooids occupy the distal third of the colony projections, parallel to the major axis of the projections, and reach a maximum size of around $4 \mathrm{~mm}$ in length when fully distended. The thorax and abdomen are 1.0 and $3.0 \mathrm{~mm}$ in length, are opaque and so the internal organs are difficult to see. Both siphons are tubular and have six slightly pointed lobes; the oral lobe is shorter than the atrial. Longitudinal musculature is formed by 5-6 fibers on each side of the thorax. The pharynx has three rows of stigmata, each with 15 slits per half row.

The abdomen is long and slender and the stomach is posterior and laterally flattened. The intestine is long with a constriction at the beginning of the ascending portion after the intestinal loop. The pyloric tubules have numerous globular projections along the intestine wall, just above the stomach, and the tubules extends twice the length of the stomach, as depicted in figure 4D of MonNiot (1983). A long and thin common tube links the pyloric gland to the mid portion of the stomach.

The testis is posterior to the stomach and has 11-13 follicles. The sperm duct is elongated and is widened at the level of the stomach. The ovary is the central to the testicular follicles and contains three oocytes. One or two larvae are incubated in the atrial cavity. The larvae are ovoid and the trunk is $0.4 \mathrm{~mm}$ long, and have three adhesive papillae very close together, supported by short peduncles. The ampullae are short and rounded, 13 on each side plus a single one in the ventral region. The tail wraps around three-quarters of the larva.

Examined material. Brazil, Paraíba: João Pessoa (Ponta do Cabo Branco, 0708'50"S, 34²4'51"W, intertidal), 1 colony, 04.x.2007, Leonel, R.M.V. leg., (LIPY UFPB-Tun-358); João Pessoa (Quebramar Cabedelo, 657'44"S, 34 50'35"W, intertidal), 1 colony, 1 slide (EUD 1.11), 25.iii.2013, Oliveira, L.M. leg., (DZUP 

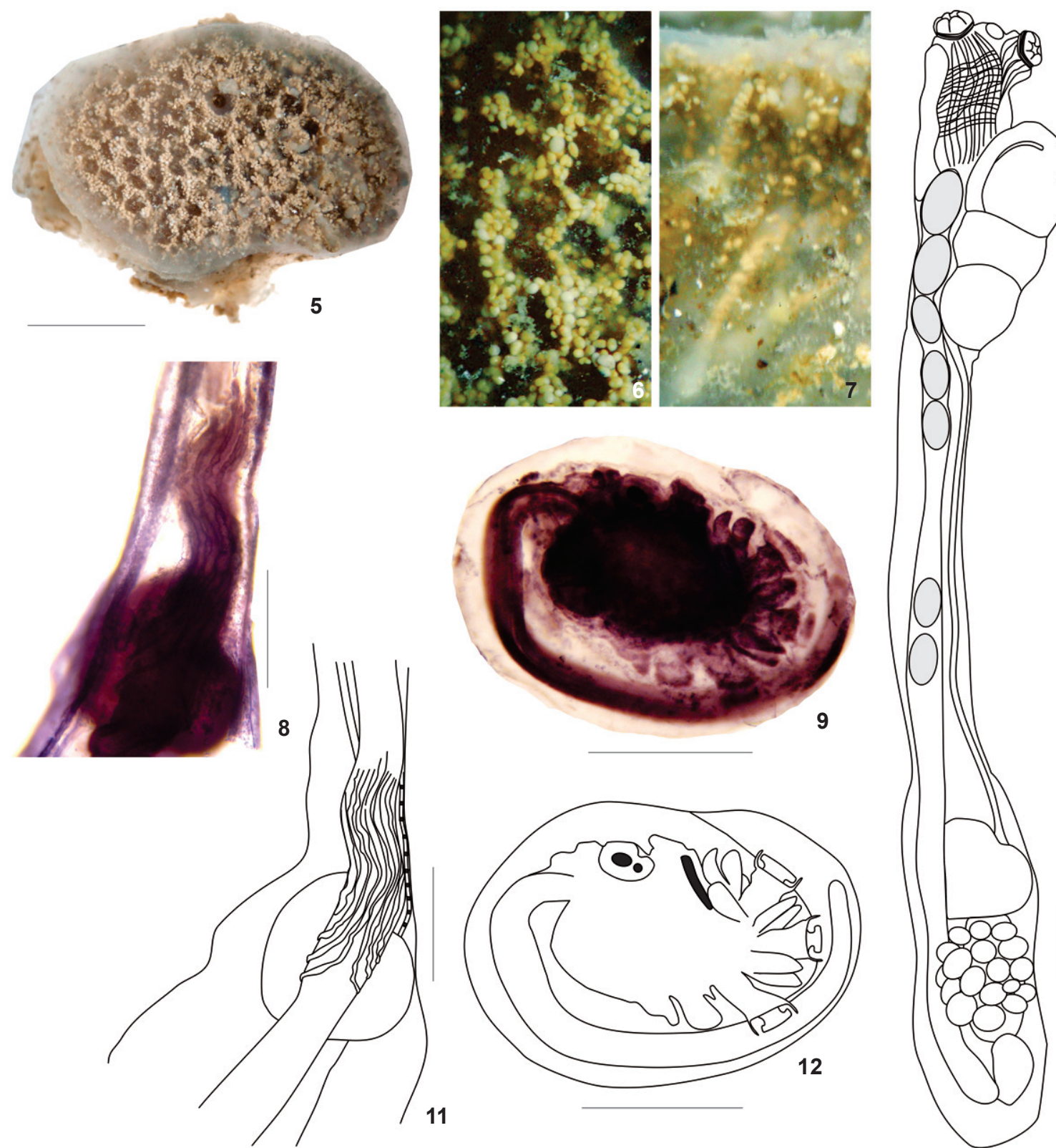

10

Figures 5-12. Eudistoma alvearium sp. nov.: (5) colony in formalin; (6) detail of the surface of the colony; (7) cross section of the colony showing the arrangement of zooids; (8) pyloric tubules; (9) larva; (10) zooid brooding embryos; (11) pyloric tubules; (12) larva. Scale bars: $5=1 \mathrm{~cm} ; 8,11=0.25 \mathrm{~mm} ; 9,10,12=0.5 \mathrm{~mm}$.

EUD-48); Bahia: Salvador (Naufrágio Germânia, $13^{\circ} 00^{\prime} 34^{\prime \prime S}$, $38^{\circ} 31^{\prime} 59^{\prime \prime}$ ), 1 colony, 10.xii.2007, Rocha, R.M. leg., (DZUP EUD-73); Espírito Santo: Vila Velha (Ilha dos Pacotes, 20²1'5.40"S, 40¹5'3.79"W, $12 \mathrm{~m}$ ), 01 colony, 13.ii. 2011. Rocha, R.M. leg., (DZUP EUD-29); Fundão (Enseada das Garças, $\left.20^{\circ} 01^{\prime} 57^{\prime \prime S}, 40^{\circ} 09^{\prime} 3 " \mathrm{~W}, 0.3 \mathrm{~m}\right), 01$ colony, 25.i.2012, Gamba, G.A. leg., (DZUP EUD-31).
Distribution. Brazil: Pará (Millar 1977); Ceará, Pernambuco, Bahia, Espírito Santo (Tito Lotufo, pers. comm.); Paraíba (this study); Paraná (Rocha \& Faria 2005, Rocha \& Kremer 2005); Santa Catarina (Rocha \& MoReno 2000, Rocha et al. 2005). Global: United States: South Carolina, Florida (VAN NAME 1945); Guadalupe (MonNiot 1983); Senegal (Pérès 1949).

Remarks. Four of the six species of Eudistoma in Brazil 

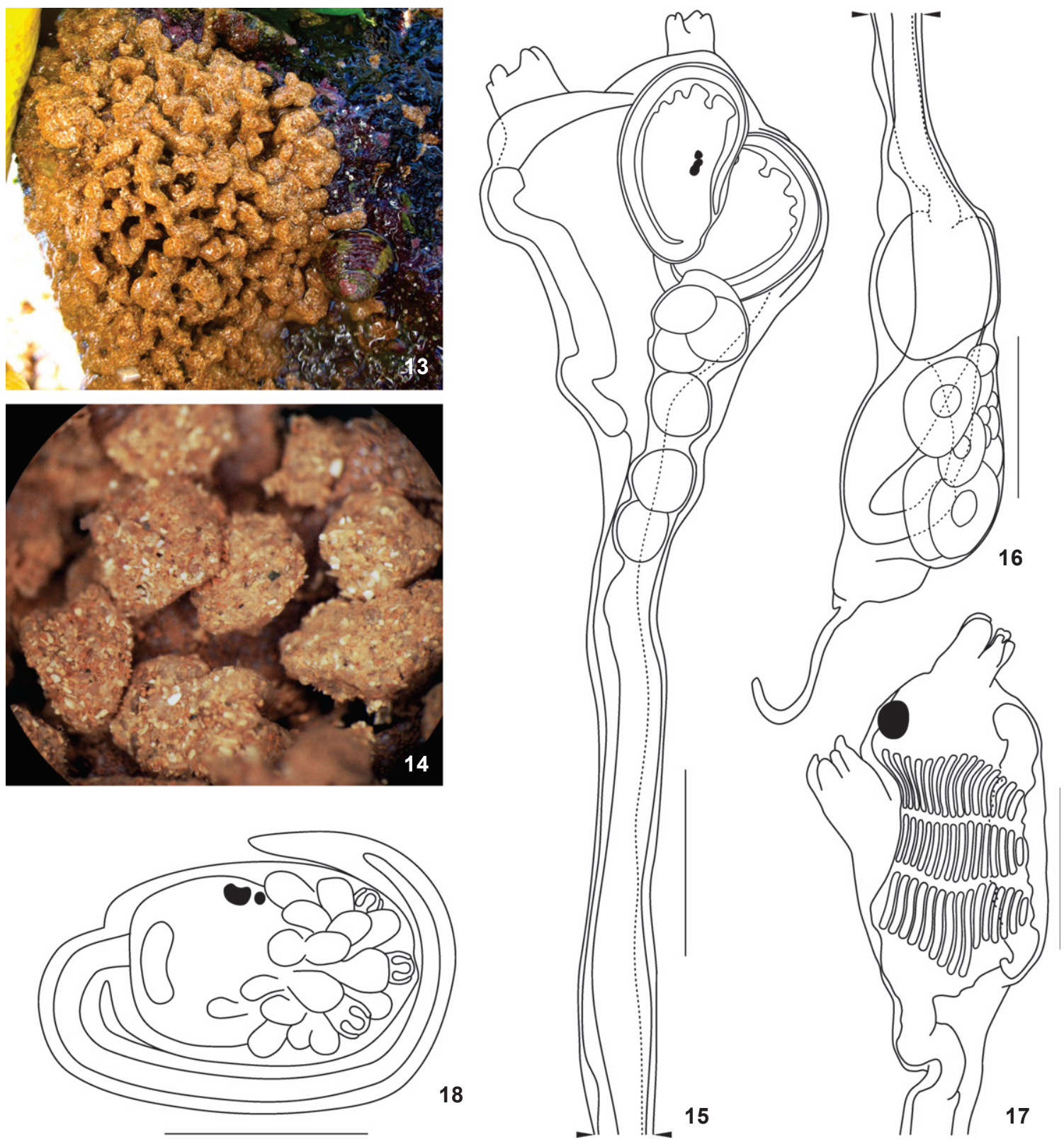

Figures 13-18. Eudistoma carolinense: (13) the colony in situ; (14) colony in detail; (15) thorax with larvae; (16) abdomen; (17) thorax; (18) larva. Scale bars: $15-17=0.4 \mathrm{~mm} ; 18=0.2 \mathrm{~mm}$.

have lobed colonies: E. vannamei, E. saldanhai, E. repens and E. carolinense. The first two lack sand in the tunic and zooids and larvae are sufficient different to be distinguished from $E$. carolinense. The description of $E$. repens does not say how it is different from E. carolinense MilLar (1977). We propose the synonymy of $E$. repens with $E$. carolinense, because of their morphological similarity, especially of the larvae. Some small differences in colony size and number of pharyngeal stigmata between the species was noted, but colony shape and larval morphology and size are very similar or identical and thus do not support them as separate species. Millar (1977) says there are six embryos and larvae in the atrial cavity, but his illustration shows only three. Our samples had two embryos in the atrial cavity, but we suggest that the number may vary. Colonies are quite similar and the small differences are probably due to the different substrates where they were found. 
Eudistoma carolinense has a disjunct distribution in tropical and in colder waters, but no records from the geographically intermediate waters of São Paulo and Rio de Janeiro. It was originally described from the southeastern United States (VAN NAME 1945) and, subsequently, in South (Millar 1977) and Central America (MonNiot 1983). The southernmost record in the Atlantic is from Santa Catarina (Rocha \& Moreno 2000), where it was possibly introduced (Rocha \& FarIa 2005). This is the first record for Paraíba. Northeastern populations are considered cryptogenic because it remains unclear whether they belong to the original tropical distribution or were transported anthropogenically.

\section{Eudistoma recifense Millar, 1977}

Figs 19-24

Eudistoma recifense Millar, 1977: 181-182 fig. 9.

Description. The colony is cushion-shaped, opaque and grayish when preserved. The tunic is translucent, cartilaginous, and smooth. The colony from Paraíba was 4.0 x $3.0 \mathrm{~cm}$ long and had approximately 45 circular depressions that mark systems, which were formed of 6-10 individuals, usually eight.

Zooids are transparent but with some black in the dorsal region of the thorax and a few black spots in the abdomen. In preserved material the pigmentation is reduced and the abdomen spots disappear over time. The most relaxed zooid was 10 $\mathrm{mm}$ long. Oral and atrial siphons are 6-lobed with a black rim. The atrial siphon is longer than the oral, lateral and oriented horizontally with pigment throughout.

Transverse musculature is conspicuous throughout the thorax, except at the base. Longitudinal musculature comprises approximately 12-14 fibers on each side of the thorax. There are 16 simple oral tentacles. The pharynx has 14-16 stigmata on each side of each row.

The abdomen is long and slender. The intestine is long and constricted at the beginning of the ascending portion, after the intestinal loop. Three to five winding pyloric tubules are on the ascending intestine, starting anterior to the stomach. The testis is in the intestinal loop just below the stomach and has approximately 18 follicles. The ovary is central to testicular follicles and contains two eggs. The anus opens at the level of the second row of pharyngeal slits.

One embryo is incubated between the thorax and the abdomen. The ovoid larva has a $0.6 \mathrm{~mm}$ long trunk, three adhesive papillae with short, wide stalks, the ventral papilla farther from the rest. Five ampullae are in the mid anterior line and one is dorso-lateral on the right side, for a total of six. The pharynx has three rows of stigmata, with 14 slits per half row. The ocellus and otolith are in a posterior position of the larva. The tail makes three-quaters of a turn and passes on the left side of the adhesive papillae.

Examined material. Brazil, Paraíba: João Pessoa (Pomar das Esponjas, $07^{\circ} 08^{\prime} 04^{\prime \prime}$ S, 34 $46^{\prime} 20^{\prime \prime} \mathrm{W}$, sublittoral), 1 colony, 1 slide (Eud 1.6), 12.i.2009, Projeto Biota Paraíba (LIPY UFPB-
Tun-206); Pernambuco: (Naufrágio do Areeiro 0803'46"S, $34^{\circ} 49^{\prime} 24^{\prime \prime} \mathrm{W}, 12 \mathrm{~m}$ ), 1 colony, 28.xi.1999, 1 slide (Poly1.59), Lotufo, T.M.C. leg. (DZUP POLY-52).

Distribution. Brazil: Ceará (Millar 1977), Paraíba and Pernambuco (this study).

Remarks. This species was first described by Millar (1977) from Pernambuco and then it was found in Ceará. This is the first record for Paraíba. It is uncommon and all previous specimens found were collected in the subtidal zone. Characteristics of our specimen are in accordance with the original description, with one exception in which the embryo in ours was not incubated in the atrial cavity as described. but rather between thorax and abdomen. Eudistoma saldanhai in Brazil is another species with a firm cartilaginous colony but it is pedunculate, zooid systems are formed by 12 individuals, the thorax lacks pigment, has fewer pharyngeal slits (10) and the larger larvae are incubated in the atrial cavity (Millar 1977).

\section{Eudistoma sp. 1}

Figs 25-32

Description. The colony is cushion-shaped and rounded, with $5.5 \mathrm{~cm}$ in diameter and $2.6 \mathrm{~cm}$ thick, adherent to the substrate by the entire base. The tunic is fully encrusted with sand and so the colony is very firm. When alive, the color of the colony is grayish, but when fixed, tends to pale brown due to the sand color on the surface.

Zooids are scattered throughout the colony forming barely visible systems and arranged in circular groups of six zooids. The zooids are perpendicular to the surface of the colony, $11 \mathrm{~mm}$ long when fully stretched, but the thorax is always small with only $2 \mathrm{~mm}$. They are transparent but the digestive system is yellowish with evident fecal pellets throughout. Both siphons are tubular with six rounded lobes at the rim. The atrial siphon is long and opens on the surface of the colony, close to the oral siphon. Thin and dense circular muscles appear along the whole extension of both siphons. The longitudinal musculature is conspicuous and consists of approximately 28-32 fibers grouped in bundles of 5-6 fibers on each side of the thorax and then extending to the posterior end of the abdomen. Thorax transverse fibers sum 42 . Around 50 oral tentacles are arranged in three rows asymmetrically distributed with longer tentacles in the last row. The pharynx has three rows of stigmata, each having 24 elongated slits.

The abdomen is over four times the length of the thorax. The stomach is posterior, elongated and has a depression at both the anterior region (in connection with esophagus) and the posterior region (in connection with the anterior intestine). The anterior intestine is narrow and as long as the stomach, followed by an ovoid post-stomach before the intestinal loop. The pyloric gland contains three parallel tubules on each side of the ascending intestine, slightly swollen at the base. The anterior portion of the pyloric tubules can wind slightly. 

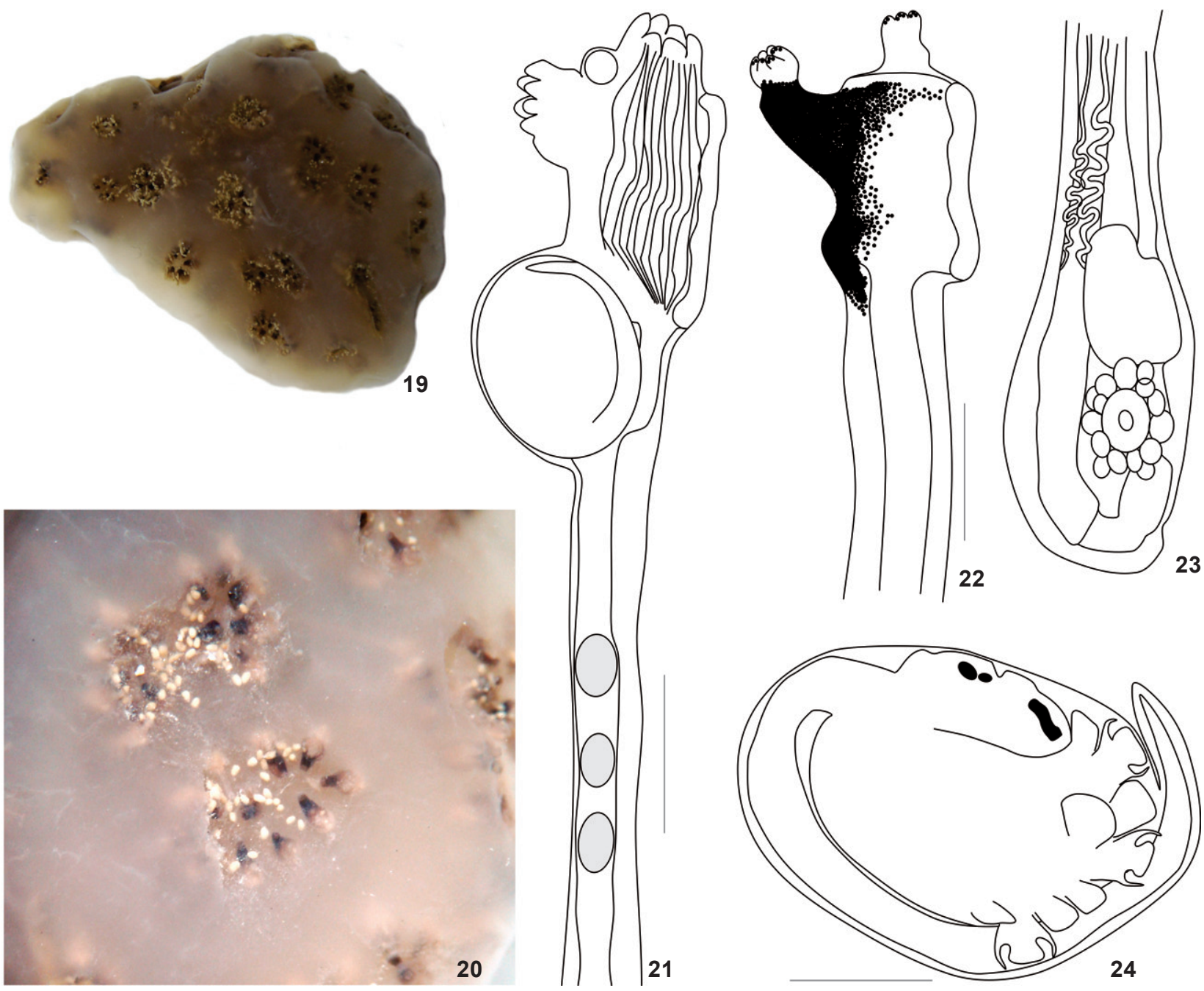

Figures 19-24. Eudistoma recifense: (19) colony in formalin; (20) detail of the surface of the colony showing organization of zooids in systems; (21) zooid with larva; (22) pigmented thorax; (23) abdomen with pyloric tubules; (24) larva. Scale bars: $21-22=0.5 \mathrm{~mm} ; 23-24=0.25 \mathrm{~mm}$.

The testis is located between the stomach and the poststomach, in the intestinal loop. It is divided into 13 pyriform follicles from which small tubules converge to a common straight sperm duct. The ovary was undeveloped and larvae were absent.

Examined material. BraziL, Espírito Santo: Vila Velha (Ilha dos Pacotes $20^{\circ} 21^{\prime} 6 " \mathrm{~S}, 40^{\circ} 15^{\prime} 4$ "W, $12 \mathrm{~m}$ ), 01 colony, 13.ii.2011, Rocha, R.M. leg., (DZUP EUD-80).

Remarks. Several Eudistoma species have sand-encrusted colonies. In the Atlantic, Eudistoma angolanum (Michaelsen, 1914) from Togo most resembles our specimen (Michaelsen 1915). The species putatively has a wide geographical distribution as reported from South Africa (Millar 1962), Japan (ТокіоKA 1954), West and East Australia (Котт 1990), but Pacific colonies have a red or purplish-black tunic and pink zooids, even when preserved (Котт 1990), which suggests that this may be a species complex. Additionally, other characters, such as the number of longitudinal and circular muscular fibers in the thorax and the number of stigmata in each half row, are also variable. Most descriptions do not show the morphology of the tubules of the pyloric gland which is unvariable in Eudistoma. Since we only have one colony, we cannot examine variability in the Brazilian population, and, due to the lack of larvae, we prefered to not yet name this species.

\section{Eudistoma sp. 2}

Figs 33-36

Description. The transparent colony is round, $2.0 \mathrm{~cm}$ in diameter and $2-3 \mathrm{~mm}$ thick, firmly adhered to the substrate, difficult to remove. Consistency is soft and gelatinous and the 

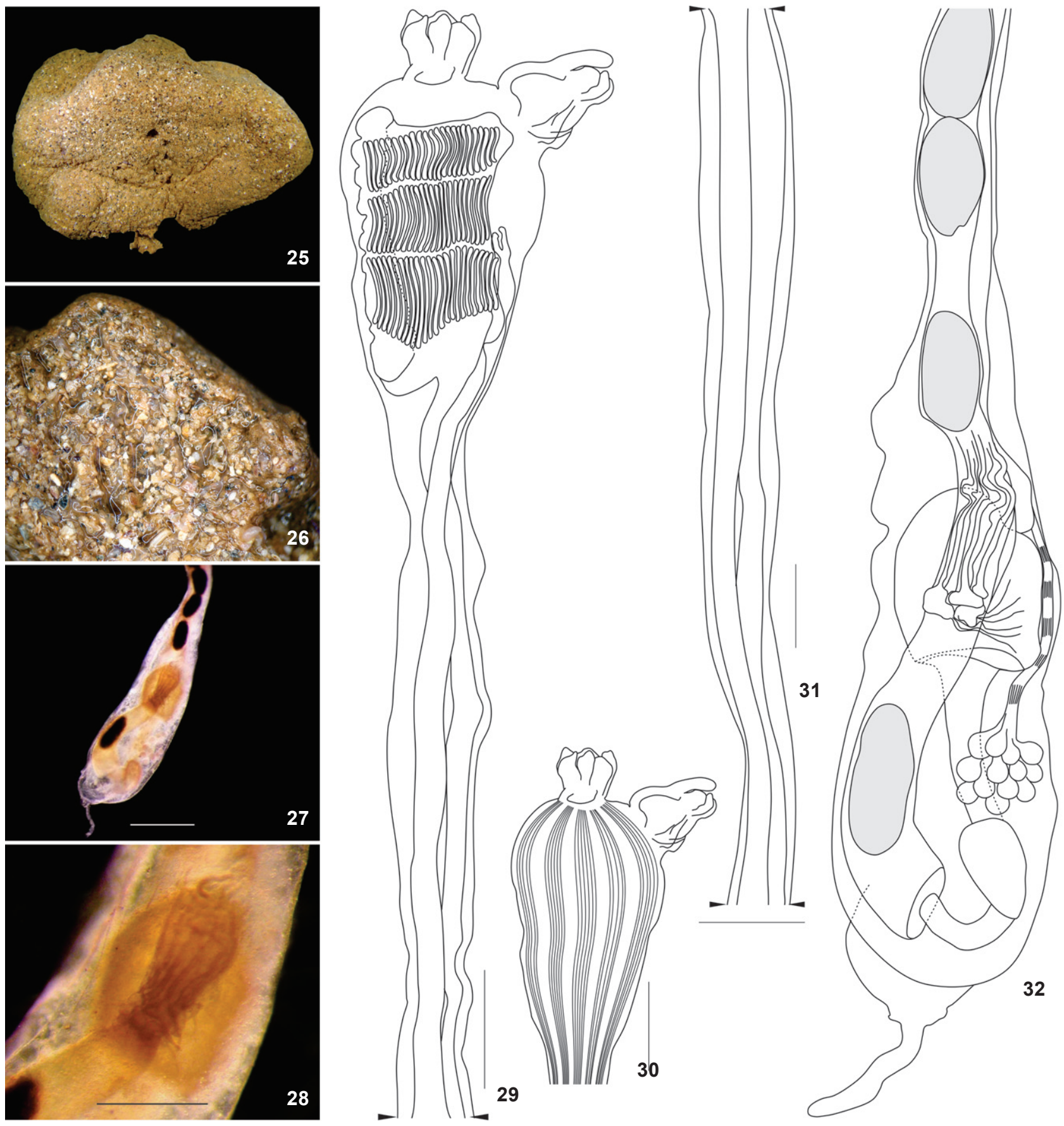

Figures 25-32. Eudistoma sp. 1: (25) colony fixed in formalin; (26) colony cross-section. (27) final portion of the abdomen; (28) abdomen in detail, showing the pyloric tubules; (29) thorax and anterior abdomen; (30) musculature pattern on the thorax; (31) the middle portion of the abdomen; (32) posterior portion of the abdomen. Scale bars: $27=1.0 \mathrm{~mm} ; 28-32=0.5 \mathrm{~mm}$.

surface is smooth and shiny without sand. Zooids do not form systems and are more concentrated in the central region of the colony.
Zooids are approximately $2.2 \mathrm{~mm}$ long, although very contracted and the body was curved due to muscle contraction. The thorax and abdomen are about 0.7 and $1.5 \mathrm{~mm}$ long, 

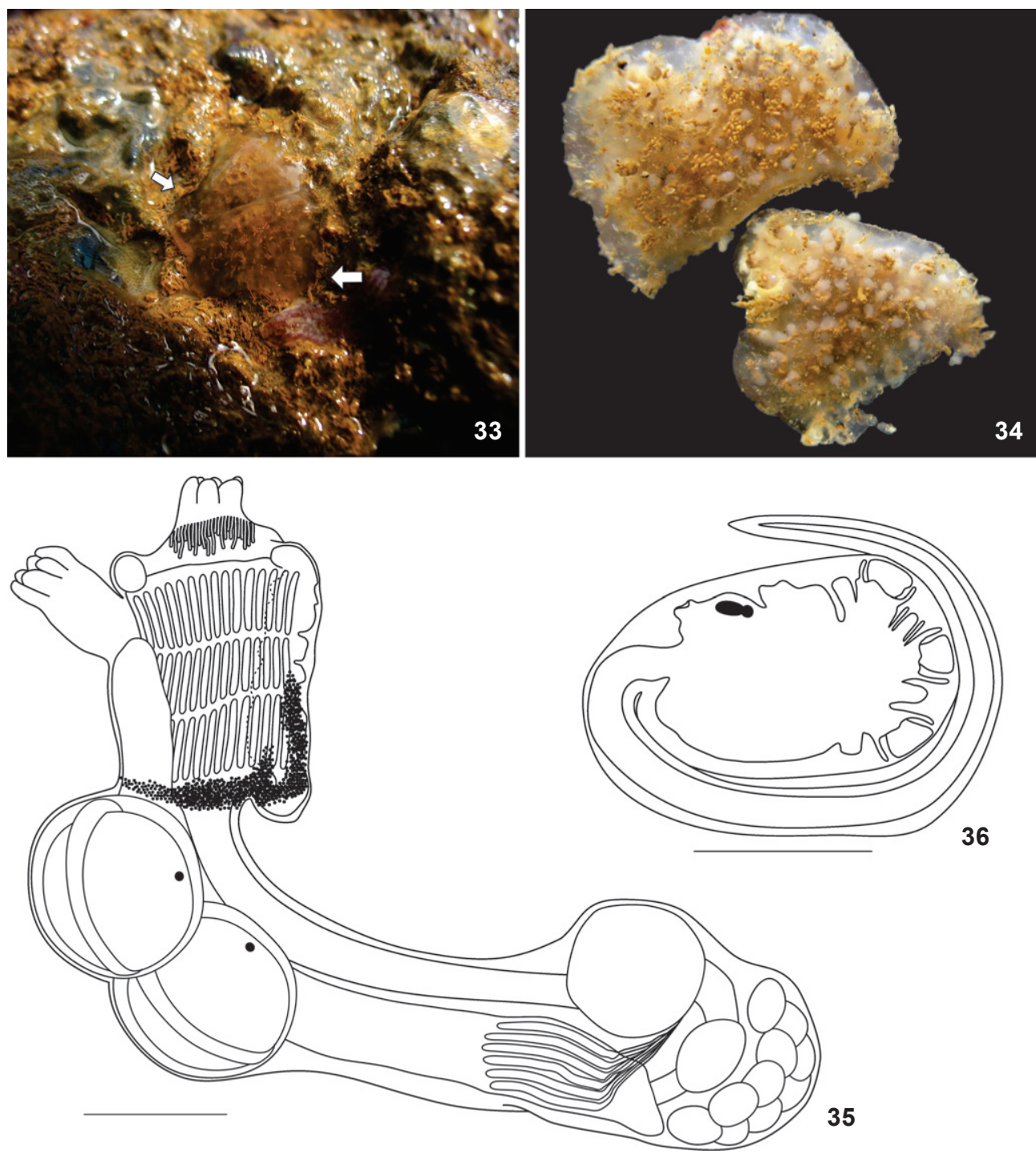

35

Figures 33-36. Eudistoma sp. 2: (33) colonies on the substrate (white arrows); (34) colonies in formalin; (35) zooid; (36) larva. Scale bars $=0.3 \mathrm{~mm}$.

respectively. The zooids are perpendicular to the surface of the colony and occupy the entire thickness. Surrounding the base of the thorax there is a band of dark pigment wider in the region close to endostyle and covering part of it. The oral siphon is short and wide, lined with six rounded lobes. The atrial siphon is tubular with six rounded lobes. The longitudinal musculature has 6-7 fibers on each side of the thorax.

There are about 25 simple oral tentacles of three sizes. The pharynx has three rows of stigmata, each half row with about 15 elongated slits. The elongated abdomen is almost three times the length of the thorax. The esophagus is long and narrow and the stomach is ovoid and located in the posterior half of the abdomen. The anterior intestine, narrower and shorter than the stomach, is followed by an ovoid post-stomach. The pyloric gland has 6 or 7 parallel tubules, anterior to the level of the stomach. The testis is posterior to the intestinal loop, at the end of the abdomen, possibly due to the state of contraction of zooids; it presents 8-10 rounded follicles. The ovary was not developed.

Larvae are ovoid, the trunk 0.6-0.8 mm long. Three large and cup-shaped adhesive papillae are supported by very short stalks. There are four central short and rounded ampullae and two additional narrow ampullae at each dorsal and ventral side of the second ampulla. The tail makes three-quaters of a turn around the larva. One or two larvae are in the anterior portion of the abdomen, just below the thorax. 
Examined material. BraziL, Espírito Santo: Fundão (Enseada das Garças $\left.20^{\circ} 01^{\prime} 57^{\prime \prime} \mathrm{S}, 40^{\circ} 09^{\prime} 32^{\prime \prime} \mathrm{W}, 0,30 \mathrm{~m}\right), 01$ colony 25.i.2012, Gamba, G.A. leg. (DZUP-EUD 79).

Remarks. With one colony, character variation for this species remains uncertain. Colonies and zooids fit the description of Eudistoma planum Pérès, 1948 (further described in Pérès 1949), but, PéRès $(1948,1949)$ did not describe either larvae or pyloric tubules, important characters for species identification. In Brazil, our specimen most closely resembles E. recifense found in Ceará and Pernambuco. But, colonies of the latter are thicker and zooids are arranged in round or oval systems (MilLar 1977) and the larvae are different (Figs 7 and 11). Eudistoma alvearium, described herein, also has a gelatinous colony but zooids can be individually recognized due to the fecal pellets, they incubate up to three embryos in the anterior abdomen and the larva have more ampullae.

\section{Eudistoma vannamei Millar, 1977}

Figs $37-45$

Eudistoma vannamei Millar, 1977: 182-184, fig. 10.

Description. The colony is encrusting, formed by several pedunculate heads, varying $1-2 \mathrm{~cm}$ in length with cylindrical stalks protruding from a sturdier and thicker base encrusted with sand. The color is yellow or orange in life and light beige in formalin.

Zooids are parallel to each other without forming systems and occupy the entire space from the surface to the base of the colony. The most relaxed zooid was $20 \mathrm{~mm}$ long, but they are usually only $10 \mathrm{~mm}$. They have orange pigment in the anterior region around the siphons, in the upper $1 / 3$ of the abdomen and scattered spots in the intestinal loop, when the animal is recently preserved, turning white or beige over time. Both siphons open at the surface of the colony, are 6lobed, short, with strong circular muscles forming a sphincter.

The body wall is transparent with conspicuous longitudinal muscles in the thorax, having 12-14 parallel fibers in each side. The transverse musculature is dense with 28-30 muscle fibers between the first and third rows of stigmata. In some zooids a muscular ring at the most anterior region of the abdomen, near the thorax was visible.

There are 32 oral tentacles. The pharynx has with three rows of stigmata, with 20-22 slits per row on each side.

The esophagus is long and straight. The anterior intestine is shorter than the stomach. The pyloric gland contains at least seven straight and parallel pyloric tubules, starting in the posterior region of the stomach. The intestinal loop has two constrictions, one between the anterior intestine and the middle intestine and followed by another prior to the ascending intestine. The anus is bilobed and ends at the level of the second row of stigmata.

The gonads form a cluster inside the intestinal loop. The testis has approximately six follicles and the sperm duct is straight; the ovary is surrounded by testicular follicles. Only one oocyte was seen. Only one large larva is incubated in the atrial cavity. The larva is ovoid and orange, between 1.2 and $1.4 \mathrm{~mm}$ long and has many brownish vesicles throughout the body wall, mainly in the anterior and posterior regions. It has three adhesive papillae and four pairs of elongated ampullae. The dorsal papillae are closer to each other. Ocellus and otolith are in the most posterior region. The tail describes 3/4 turn around the larva and passes through the left side of the adhesive papillae.

Examined material. Brazil, Paraíba: Mataraca (Barra de Camaratuba $6^{\circ} 36^{\prime} 06^{\prime \prime} \mathrm{S}, 34^{\circ} 57^{\prime} 57^{\prime \prime} \mathrm{W}$, intertidal), 1 colony, 13.iii.2013, Oliveira, L.M. leg. (DZUP EUD-47); Baia da Traição, $\left(6^{\circ} 41^{\prime} 19^{\prime \prime} \mathrm{S}, 34^{\circ} 55^{\prime} 60^{\prime \prime} \mathrm{W}\right.$, intertidal), 1 colony, 12.iii.2013, Oliveira, L.M. leg. (DZUP EUD-46); Rio Tinto (Barra de Mamanguape, $6^{\circ} 46^{\prime} 11^{\prime \prime} \mathrm{S}, 34^{\circ} 55^{\prime} 10^{\prime \prime} \mathrm{W}$, intertidal), 1 colony, 11.ii.2009, Projeto Biota Paraíba, (LIPY UFPB-Tun-251); João Pessoa (Ponta do Cabo Branco, 0708'50"S, 34²4'51"W, intertidal), 1 colony, 17.ii.1980, Christoffersen, M.L. leg. (LIPY UFPBTun-121); (Ponta do Cabo Branco, 0708'50"S, 3447'51"W, intertidal), 1 colony, 28.iii.2013, Oliveira, L.M. leg. (DZUP EUD45); João Pessoa (Ponta do Seixas, $7^{\circ} 09^{\prime} 21^{\prime \prime} \mathrm{S}, 34^{\circ} 47^{\prime} 10^{\prime \prime} \mathrm{W}$, infralitoral), 1 colony, 10.xii.1984, Dijek, P.M. leg. (LIPY UFPBTun-83); Conde (Praia de Maceiozinho, $7^{\circ} 16^{\prime} 19{ }^{\prime \prime} \mathrm{S}, 34^{\circ} 48^{\prime} 07^{\prime \prime} \mathrm{W}$, intertidal), 1 colony, 06.v.2009, Projeto Biota Paraíba (LIPY UFPB-Tun-305); Conde (Carapibus, $7^{\circ} 16^{\prime} 19^{\prime \prime} S, 34^{\circ} 48^{\prime} 07^{\prime \prime} \mathrm{W}$, intertidal), 3 colonies, 1 slide (EUD 1.12), 26.iii.2013, Oliveira, L.M. leg. (DZUP EUD-42; 43; LIPY UFPB-Tun-375); Conde (Coqueirinho, $7^{\circ} 19^{\prime} 14^{\prime \prime} \mathrm{S}, 34^{\circ} 47^{\prime} 40^{\prime \prime} \mathrm{W}$, intertidal), 2 colonies, 27.iii.2013, Oliveira, L.M. leg. (DZUP EUD-44; LIPY UFPB-Tun376); Conde (Praia de Tabatinga, $7^{\circ} 16^{\prime} 19^{\prime \prime} S, 34^{\circ} 48^{\prime} 07^{\prime \prime} \mathrm{W}$, intertidal), 1 colony, 10.ii.2009, Projeto Biota Paraíba (LIPY UFPBTun-202); Pitimbú (Recife da Galé, 07²8'01"S, 3447'35"W, intertidal), 1 colony, 12.xii.2008, Projeto Biota Paraíba (LIPY UFPB-Tun-35); Alagoas, Marechal Deodoro (Praia do Francês, $9^{\circ} 43^{\prime}$ S, 3554' W, intertidal), 1 colony, 26.xi.1999, Lotufo, T.M.C. leg. (DZUP POLY-51); Bahia: Salvador (Naufrágio Germânia, $\left.13^{\circ} 00^{\prime} 34^{\prime \prime S}, 38^{\circ} 31^{\prime} 59^{\prime \prime} \mathrm{W}, 8 \mathrm{~m}\right), 1$ colony, 1 slide (Eud 1.16), 10.xii.2007, Rocha, R.M. leg. (DZUP EUD- 72).

Distribution. Brazil: Amapá and Bahia (Millar 1977); Paraíba, Alagoas (this study).

Remarks. The color, shape and size of the colony and size of the larva make clear the identification of this species. However, small differences in larval morphology from the original description were found: vesicles were distributed throughout the body and not only in the anterior and posterior regions, and four pairs of ampullae were seen, instead of five (Millar 1977). Between the medial and ventral adhesive papillae, there was one wide and long ampulla and not two (as in MiLLAR 1977, fig. 10); this difference may indicate that the larvae were still developing. Eudistoma olivaceum (Van Name, 1902) colonies are similar to E. vannamei, but beige and translucent. The zooid has a black spot in the region of the dorsal ganglion and on the most anterior region of the endostyle and more than 20 testicular follicles. Eudistoma magalhaensis (Michaelsen, 1907) 

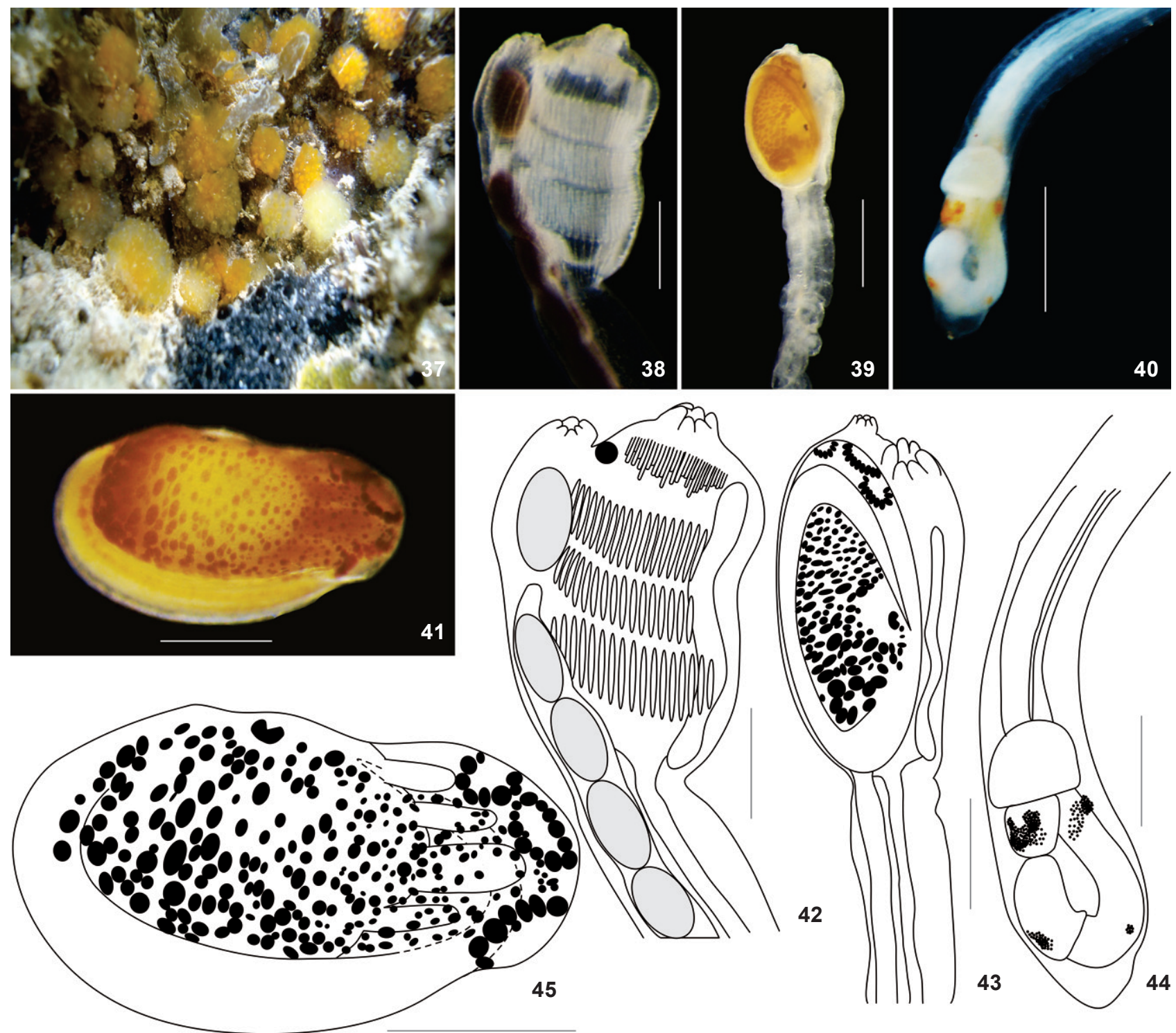

Figures 37-45. Eudistoma vannamei: (37) the colony in situ; (38) thorax; (39) thorax with larva (orange); (40) abdomen; (41) larva; (42) thorax; (43) thorax with larva; (44) abdomen; (45) larva showing the vesicles. Scale bars: 38, 40-45=0.5 mm; $39=1.0 \mathrm{~mm}$.

from the Pacific also has colonies similar to E. vannamei, but the larva differs in the number and arrangement of ampullae: alternating between the papillae with a pair on the side. The anterior end of the ampullae between the dorsal and medial papillae is divided (SANAMYAN \& SCHORIES 2007).

Eudistoma vannamei is endemic to the northeastern coast of Brazil, with previous records for the states of Amapá, Ceará and Bahia (Millar 1977) and this is the first record for Paraíba. It is quite abundant in the intertidal coast of Paraíba, but rare in Bahia, which suggests that this is the southern limit of its distribution.
Eudistoma versicolor Rocha \& Oliveira, sp. nov. Figs $46-55$

Description. The colony is $2.5-6 \mathrm{~cm}$ long and $0.7-3.0 \mathrm{~cm}$ thick. It is massive, encrusting and may be cushion or rounded in shape. In some cases, more vertical growth leaves the base of the colony narrower than the surface. In life, colony color varies and can be purple, blue, brown, gray and white, while in formalin they become dark purple, almost black, brown or green. The tunic is translucent with a smooth surface, but with encrustations (sand grains, bryozoans, shells of mollusks and calcare- 
ous algae) and fecal pellets at the base of the colony. The tunic also has vacuole and pigment cells and siliceous spicules of sponges in low density on the whole surface of the colony.

Zooids are completely embedded in the tunic in circular systems of 4-9 individuals (most commonly 5-7) with atrial siphons directed to the center of the circle. In most cases zooids are contracted, about $7 \mathrm{~mm}$ in length, but some may reach $10 \mathrm{~mm}$, and are uncolored and transparent. Both siphons are tubular and lobed, with six rounded lobes, each opening on the surface of the colony. The oral siphon is smaller than the atrial siphon which faces upwards. Circular musculature is conspicuous at the base of the siphons, forming a band just below the lobes. Longitudinal musculature is conspicuous and forms lateral fibers from the thorax to the ventral region of the abdomen, where they unite. Longitudinal musculature has 18-25 fibers on each side of the thorax, grouped in bundles of 8 at the level of the first row of stigmata and extending to the end of the abdomen. The transverse musculature, with 17-20 fibers, is in the central region of the thorax between the first and third row of stigmata; fibers are closer together in the anterior region of the thorax.

There are about 12 simple oral tentacles. The pharynx has 14-16 pharyngeal slits on each side of each row. The esophagus is long and straight. The stomach is globular and has a depression in the upper portion where it is penetrated by the esophagus. The anterior intestine and medium intestine are short. The pyloric gland is formed by six straight and parallel tubules slightly sinuous at the level of the anterior region of the stomach. The intestinal loop has two constrictions, one between the anterior intestine and medium intestine and other between the medium and ascendent intestine. The proximal portion of the rectum is wide. The anus is bilobed, opening between the second and third row of pharyngeal slits. One or two stoloniferous vessels can be short or long.

The gonads are in the intestinal loop, with the testis and ovary posterior to the stomach, forming a cluster. The testis has $12-18$ follicles and the sperm duct is straight, while the ovary is in the central region with 1-2 oocytes. Usually one embryo is incubated at a time within the atrial cavity (but 1-3 have been seen). The larva is oval, measuring $0.8 \mathrm{~mm}$ in trunk length. The three adhesive papillae have short and broad stalks, far apart, and of the six ectodermal ampullae, four are in the anterior midline between the adhesive papillae and two are lateral. The pharynx has three rows of stigmata, containing 10-12 slits on each side of the thorax. The ocellus and otolith are in a central position. The tail describes $1 / 2$ turn around the left side of the adhesive papillae. Vacuole cells are in the tunic of the larva.

Type material. Holotype: BraziL, Paraíba: Pitimbú (Recife da Galé, $07^{\circ} 28^{\prime} 01^{\prime \prime} \mathrm{S}, 34^{\circ} 47^{\prime} 35^{\prime \prime} \mathrm{W}$, intertidal) 1 colony, 1 slide (Eud 1.4), 12.xii.2008, Projeto Biota Paraíba (MZUSP 00038). Paratypes: Brazil, Paraíba: João Pessoa (Recife do Seixas, $7^{\circ} 9^{\prime} 21^{\prime \prime S}, 34^{\circ} 47^{\prime} 10^{\prime \prime} \mathrm{W}$, infralitoral), 1 colony, 25.iii.2008, Projeto Biota Paraíba (LIPY UFPB-Tun-308); Bahia: Salvador (Quebramar
Norte, $12^{\circ} 58^{\prime} 52^{\prime \prime S}, 38^{\circ} 30^{\prime} 57^{\prime \prime} W, 7-9$ m), 1 colony, 06.viii.1999, Rocha, R.M. leg. (DZUP EUD-06); Salvador (Quebramar Sul, $\left.12^{\circ} 58^{\prime} 22^{\prime \prime S}, 38^{\circ} 31^{\prime} 09^{\prime \prime W}, 9-11 \mathrm{~m}\right), 1$ colony, 06.viii.1999, Rocha, R.M. leg. (DZUP EUD 07).

Additional Material. Brazil, Paraíba: Baia da Traição (641'19"S, 3455'60"W, intertidal), 1 colony, 1 slide (Eud 1.5), 05.v.2008, Projeto Biota Paraíba (LIPY UFPB-Tun-187); Baia da Traição (6 $6^{\circ} 1^{\prime} 19^{\prime \prime} S, 34^{\circ} 55^{\prime} 60^{\prime \prime} \mathrm{W}$, intertidal), 2 colonies, 12.iii.2013, Oliveira, L.M. leg. (DZUP EUD-49, 50); Rio Tinto (Barra de Mamanguape, $6^{\circ} 46^{\prime} 11^{\prime \prime} \mathrm{S}, 34^{\circ} 55^{\prime} 10^{\prime \prime} \mathrm{W}$, infralitoral), 1 colony, 11.ii.2009, Projeto Biota Paraíba (LIPY UFPB-Tun-240); João Pessoa (Ponta do Cabo Branco, 0708'50"S, 3447'51"W, intertidal), 2 colonies, 28.iii.2013, Rocha, R.M. leg. (LIPY UFPBTun-383, 388); João Pessoa (Ponta do Cabo Branco, 0708'50"S, $34^{\circ} 47^{\prime} 51$ "W, intertidal), 2 colonies, 28.iii.2013, Rocha, R.M. leg. (DZUP EUD- 63, 64); João Pessoa (Recife do Seixas, $7^{\circ} 9^{\prime} 21^{\prime \prime}$, $34^{\circ} 47^{\prime} 10^{\prime \prime} \mathrm{W}$ ), infralitoral, 2 colonies, 1 slide (Eud 1.7), 23.xii.2008, Projeto Biota Paraíba (LIPY UFPB-Tun-301; 303); Conde (Praia de Carapibus, $7^{\circ} 16^{\prime} 19^{\prime \prime} S, 34^{\circ} 48^{\prime} 07^{\prime \prime} \mathrm{W}$, intertidal), 2 colonies, 08.iii.2013, Projeto Biota Paraíba (LIPY UFPB-Tun-168; 182); Conde (Praia de Carapibus, $7^{\circ} 16^{\prime} 19^{\prime \prime S}, 34^{\circ} 48^{\prime} 07^{\prime \prime} \mathrm{W}$, intertidal), 5 colonies, 1 slide (Eud 1.13), 26.iii.2013, Rocha, R.M. leg. (DZUP EUD- 51; 52; 53; 54; 55); Conde (Praia de Carapibus, $7^{\circ} 16^{\prime} 19$ "S, $34^{\circ} 48^{\prime} 07^{\prime \prime} \mathrm{W}$, intertidal), 2 colonies, 26.iii.2013, Rocha, R.M. leg. (LIPY UFPB-Tun-380; 381); Conde (Praia de Coqueirinho, $7^{\circ} 19^{\prime} 14^{\prime \prime} \mathrm{S}, 34^{\circ} 47^{\prime} 40^{\prime \prime} \mathrm{W}$, intertidal), 2 colonies, 03.vi.2008, Projeto Biota Paraíba (LIPY UFPB-Tun-152; 154); Conde (Praia de Coqueirinho, $7^{\circ} 19^{\prime} 14^{\prime \prime} \mathrm{S}, 34^{\circ} 47^{\prime} 40^{\prime \prime} \mathrm{W}$, intertidal), 2 colonies, 27.iii.2013, Rocha, R.M. leg. (LIPY UFPB-Tun-383; 384); Conde (Praia de Coqueirinho, $7^{\circ} 19^{\prime} 14^{\prime \prime} \mathrm{S}, 34^{\circ} 47^{\prime} 40 " \mathrm{~W}$, intertidal), 2 colonies, 3 slides (Eud 1.1; 1.2, 1.14), 27.iii.2013, Rocha, R.M. leg. (DZUP EUD- 58, 59); Conde (Praia de Tabatinga, $7^{\circ} 16^{\prime} 19^{\prime \prime} \mathrm{S}$, $34^{\circ} 48^{\prime} 07^{\prime \prime} \mathrm{W}$, intertidal), 1 colony, 10.ii.2009, Projeto Biota Paraíba (LIPY UFPB-Tun-235); Pitimbú (Recife da Galé, $07^{\circ} 28^{\prime} 01^{\prime \prime} \mathrm{S}, 34^{\circ} 47^{\prime} 35^{\prime \prime} \mathrm{W}$, intertidal), 2 colonies, 12.xii.2008, Projeto Biota Paraíba (LIPY UFPB-Tun-20; 189); Pernambuco: Goiana (Ponta de Pedras, $07^{\circ} 37^{\prime} 17^{\prime \prime S}$, 34 $48^{\prime} 15^{\prime \prime} \mathrm{W}$, intertidal), 1 colony, 13.xii.2012, João Nogueira leg. (DZUP EUD-69); Bahia: Salvador (Naufrágio Boa Viagem, 1256’6"S, 38³0’42"W, 7-8 m), 1 colony, 3 slides (Eud 1.3; Poly.1.89; 1.99), 03.viii.1999, Rocha, R.M. leg. (DZUP EUD-01); Salvador (Quebramar Norte, $\left.12^{\circ} 58^{\prime} 52^{\prime \prime S}, 38^{\circ} 30^{\prime} 57^{\prime \prime W}, 7-9 \mathrm{~m}\right), 2$ colonies, 06.viii.1999, 01.viii.1999, Rocha, R.M. leg. (DZUP EUD-04; 05); Salvador (Quebramar Sul, 1258'11"S, 38³1'14"W, 9-11 m), 2 colonies, 4 slides (Poly.1.92; Poly.1.97; 1.98; Eud 1.10), 06.viii.1999, Rocha, R.M. leg. (DZUP EUD-02; 08); Salvador (Porto da Barra, $\left.13^{\circ} 00^{\prime} 37^{\prime \prime S}, 38^{\circ} 31^{\prime} 41^{\prime \prime W}, 5 \mathrm{~m}\right), 1$ colony, 1 slide (Eud 1.4), 09.xii.2007, Rocha, R.M. leg. (DZUP EUD- 74); Salvador (Farol Humaitá, $12^{\circ} 55^{\prime} 43^{\prime \prime}$ S, 38 31'7"W, 3-4 m), 1 colony, 2 slides (Poly 1.90; 1.91), 05.viii.1999, Rocha, R.M. leg. (DZUP POLY-53); Salvador (Naufrágio Germânia, 1300’34"S, 38³1'59"W, 8 m), 4 colonies, 2 slides (Eud 1.11; 1.12), 10.xii.2007, 04.iii.2012, Rocha, R.M. leg. (DZUP EUD- 70, 71); Salvador (Naufrágio Blackadder, 

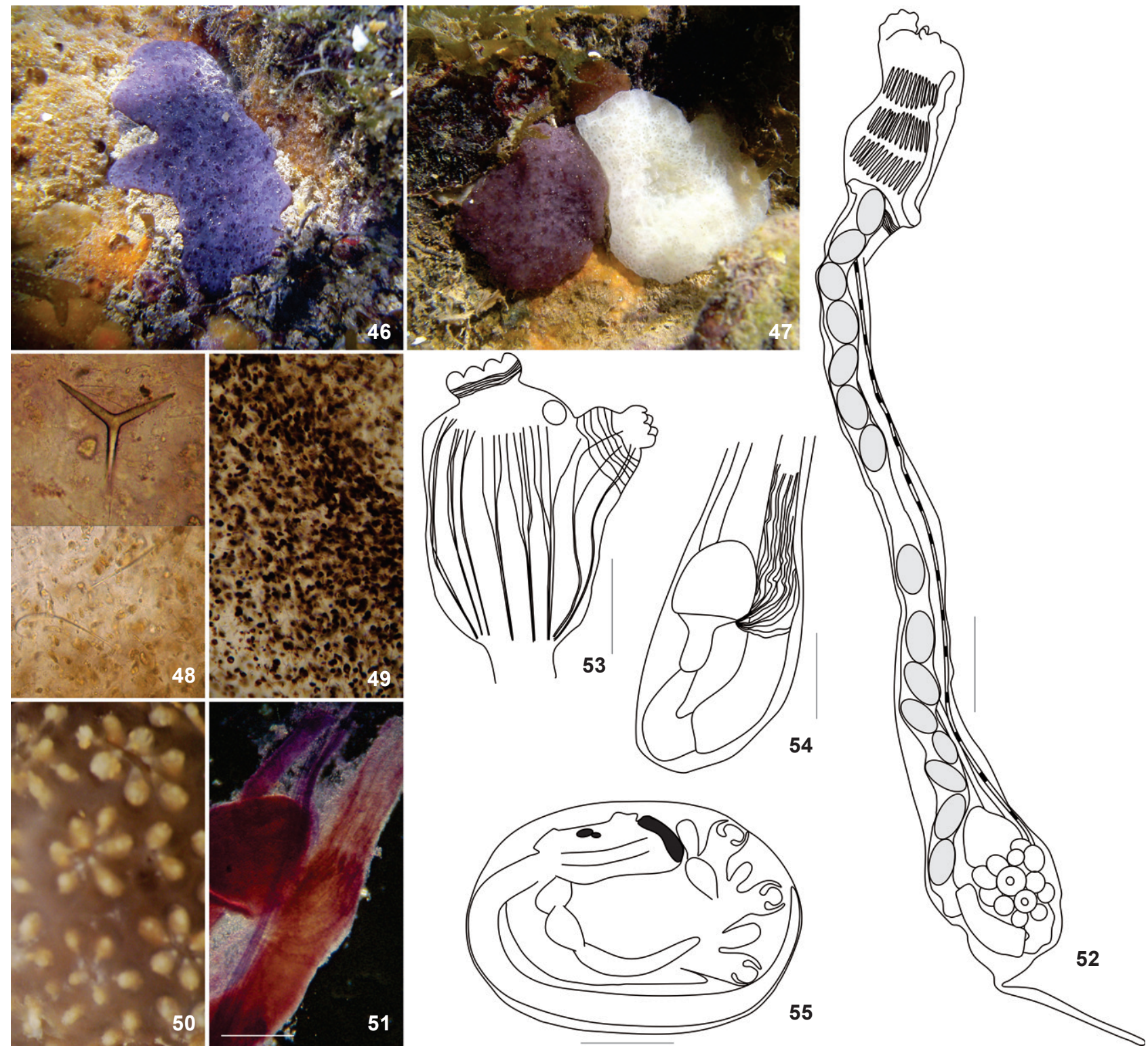

Figures 46-55. Eudistoma versicolor sp. nov.: (46) and (47) colonies in situ with four different color morphs; (48) siliceous spicules of sponges found in the tunic; (49) pigment cells in the tunic; (50) detail of the surface of the colony showing zooids arranged in systems; (51) pyloric tubules; (52) thorax and anterior abdomen; (53) longitudinal muscles grouped in bundles along the thorax; (54) pyloric tubules; (55) larva. Scale bars: $51,55=0.25 \mathrm{~mm} ; 52,54=0.5 \mathrm{~mm} ; 53=0.2 \mathrm{~mm}$.

$12^{\circ} 56^{\prime} 06^{\prime \prime} \mathrm{S}, 38^{\circ} 30^{\prime} 42^{\prime \prime} \mathrm{W}, 7 \mathrm{~m}$ ), 4 colonies, 4 slides (Eud 1.5; 1.6; 1.13; 1.15), 14.xii.2007, Rocha, R.M. leg. (DZUP EUD-68).

Etymology. The species epithet is derived from latin and refers to the variable colors of the colonies (versicolor $=$ of various colors).

Remarks. Not to be confused with the purple colonies that become almost black in formaldehyde in Eudistoma almadiense Pérès, 1953 which has colonies smaller than $1 \mathrm{~cm}$ and $2 \mathrm{~mm}$ thick with $1-2 \mathrm{~mm}$ zooids and maximum of 12 testicular follicles. Also different, Eudistoma hepaticum (Van Name, 1921) has a slightly wrinkled colony surface with depressions in the tunic, indicating the circular systems of zooids. Pyloric tubules are parallel and very close together, with the end region rounded, like a bulb. Larvae have many ectodermal ampullae and the tail makes 3/4 of a turn. Eudistoma clivosum Sanamyan et al., 2010 also resembles the purple E. versicolor 
but was found in cold waters of the Pacific, in Chile, very different from the warm waters of the tropical coast of Brazil, and there are a few differences that distinguish the two species. Colonies of E. clivosum have small lobes on the surface and the circular systems are sometimes indistinguishable, with only four individuals. Zooids are not larger than $4.5 \mathrm{~mm}$ and have only 9-10 pharyngeal slits on each side of the pharynx. The larval adhesive papillae alternate with three ampullae. Eudistoma spiculiferum Millar, 1977 resembles brown colonies, but have calcareous spicules, zooids are only $5 \mathrm{~mm}$ long, usually orange and may have dark pigmentation in the abdomen. The larva is orange and contains numerous small vesicles.

\section{ACKNOWLEDGMENTS}

We thank Martin L. Christoffersen for the loan of material from Tunicata Collection of the Laboratory of Marine Invertebrates Paul Young of the Federal University of Paraíba. James J. Roper, Silvio Felipe, Roniere M. Oliveira, Rudá A. Lucena, and Ane I. Serrano for help during the collection of specimens, with permission ICMBio \#36512. Thanks to James J. Roper for his review of the English. The work was supported by CAPES (scholarship to LMO and GAG) and CNPq (research grant to RMR). This is 1898 Contribution of the Departamento de Zoologia, Universidade Federal do Paraná.

\section{LITERATURE CITED}

CAullery, M. 1909. Recherches sur les synascidien du genre Colella et considerations sur la famille des Distomidae. Bulletin Scientifiques de la France et de la Belgique 42: 7-59.

Kotт, P. 1990. The Australian Ascidiacea Part 2, Aplousobranchia (1). Memoirs of the Queensland Museum 29 (1): 1-266.

MichaelSen, W. 1915. Tunicata. Beitrage zur Kenntnis der Meeresfauna Westafrikas 11: 312-518.

Michaelsen, W. 1919. Die Krikobranchen Ascidien des westlichen Indischen Ozeans: Claveliniden und Synoiciden. Jahrbuch der Hamburgischen Wissenschaftlichen Anstalten 36: 71-102.

MillaR, R.H. 1962. Further Descriptions of South African Ascidians. Annals of South African Museum 46 (7): 113-221.

Millar, R.H. 1977. Ascidians (Tunicata: Ascidiacea) from the Northern and North-Eastern Brazilian shelf. Journal of Natural History 11: 169-223.

MonNIOT, F. 1978. Quelques Didemnidae et Polycitoridae (Ascidiacea) de Kerguelen. Annales de l'Institut Océanographique 54: 163170.

Monniot, F. 1983. Ascidies littorales de Guadeloupe V. Polycitoridae. Bulletin du Muséum National D'Histoire Naturelle, 4 ser., 4 (5A): 999-1019.

Submitted: 04.XII.2013; Accepted: 17.I.2014. Editorial responsibility: Walter A.P. Boeger

ZOOLOGIA 31 (2): 195-208, April, 2014
Monniot, C. \& F. Monniot. 1972. Clé mondiale des genres d'ascidies. Archives de Zoologie Expérimentable et Générale 113: 311-367.

Pérès, J.M. 1948. Sur une collection d'ascidies de la zone intercotidale de Dakar. Bulletin du Muséum National D'Histoire Naturelle, 2 ser., 20 (1): 87-95.

Pérès, J.M. 1949. Contribution à l'étude des Ascidies de la côte occidentale d'Afrique. Bulletin de l'Institut français d'Afrique noire 11: 159-207.

RitTer, W.E. \& R.H. ForsYTH. 1917. Ascidian of the littoral zone of southern California. University of California Publications in Zoology 16: 439-512.

Rocha, R.M. \& N.Y.K. BonNet. 2009. Eudistoma clavatum sp. nov. (Tunicata: Ascidiacea: Polycitoridae) from Brazil. Marine Biodiversity Records 2: 1-4. doi:10.1017/S1755267208000031.

Rocha, R.M. \& S.B. Faria. 2005. Ascidians at Currais Islands, Paraná, Brazil: taxonomy and distribution. Biota Neotropica 5: 1-20. doi: 10.1590/S1676-06032005000300013.

ROCHA, R.M. \& L.P. KREMER. 2005. Introduced Ascidians in Paranaguá Bay, Paraná, southern Brazil. Revista Brasileira de Zoologia 22: 1170-1184. doi: 10.1590/S0101-81752005000400052.

Rocha, R.M. \& T.R. Moreno. 2000. Ascidians associated with Eudistoma carolinense Van Name, 1945 with description of a new species of Polycarpa. Ophelia 52: 916. doi: 10.1080/ 00785236.1999.10409415.

Rocha, R.M.; T.R.Moreno \& R. Metri. 2005. Ascídias (Tunicata, Ascidiacea) da Reserva Biológica Marinha do Arvoredo, Santa Catarina, Brasil. Revista Brasileira de Zoologia 22: 461476. doi: 10.1590/S0101-81752005000200024.

SANAMYAN, K. \& D. Schories. 2007. Redescription of Eudistoma magalhaensis (Michaelsen, 1907) (Ascidiacea) from Guaitecas Islands, Chile. Zootaxa 1514: 65-68.

Shenkar, N.; A. Gittenberger; G. LamberT; M. Rius; R.M. Rocha, R.; B.J. Swalla \& X. Turron. 2013. Ascidiacea World Database. Available online at: http://www.marinespecies.org/ascidiacea/ aphia.php?p=taxdetails\&id=103465. [Accessed: 07/I/2014].

Токіока, T. 1942. Ascidians found on the mangrove trees in Iwayama Bay, Palao. Palao Tropical Biological Station Studies 2 (3): 499-507.

Токіока, T. 1954. Contribution to Japanese ascidian fauna. 7. Invertebrate fauna of the intertidal zone of the Tokara Islands. 7. Ascidians. Publications of Seto Marine Biology Laboratory 3 (3): 239-264.

VAN NAME, W.G. 1921. Ascidians of the West Indian region and Southeastern United States. Bulletin American Museum of Natural History 44: 283-494.

VAN NAME, W.G. 1945. The North and South American Ascidians. Bulletin of the American Museum of Natural History 84: $1-476$. 


\section{Errata for ZOOLOGIA volume 31(2), page 201}

The correct version for Figures 23 and 24 is presented below:
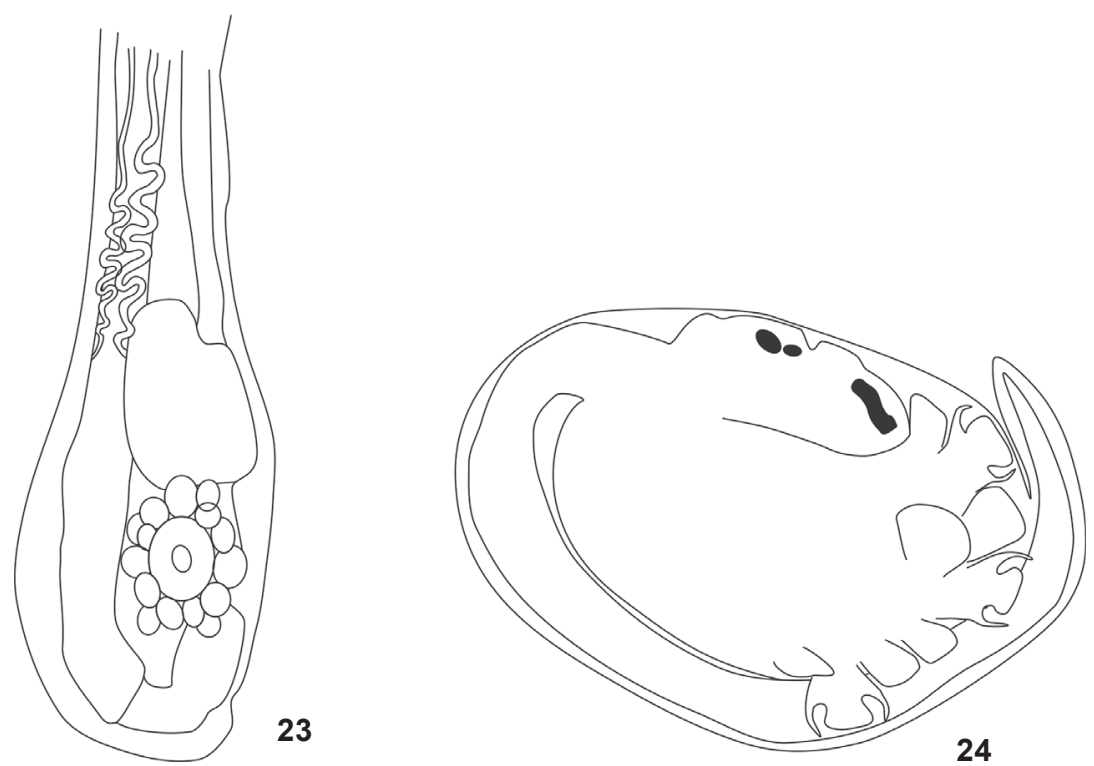

All changes are already incorporated in the online version of these articles available at http://www.scielo.br/zool 